MECCA

A Literary History of the

Muslim Holy Land F. E. Peters

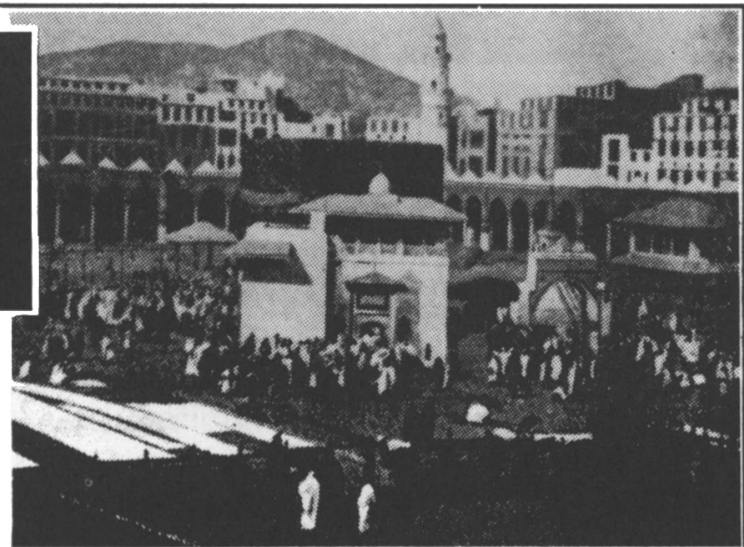

For the non-Muslim, Mecca is the most forbidden of Holy Cities-and yet, in many ways it is the best known. Muslim historians and geographers have studied it, and countless pilgrims and travelers have left behind lively and well-publicized accounts of life in Mecca and its associated shrine-city of Medina. The stories of all these figures, holy men and heathens alike, come together in this book to offer a remarkably revealing literary portrait of the city's traditions and urban life and of the surrounding area.

Closely following the publication of F. E. Peters's The Hajj, which describes the perilous pilgrimage itself from the travelers' perspectives, this collection of writings and commentary completes the historical travelogue.

Cloth: \$29.95 ISBN 0-691-03267-X

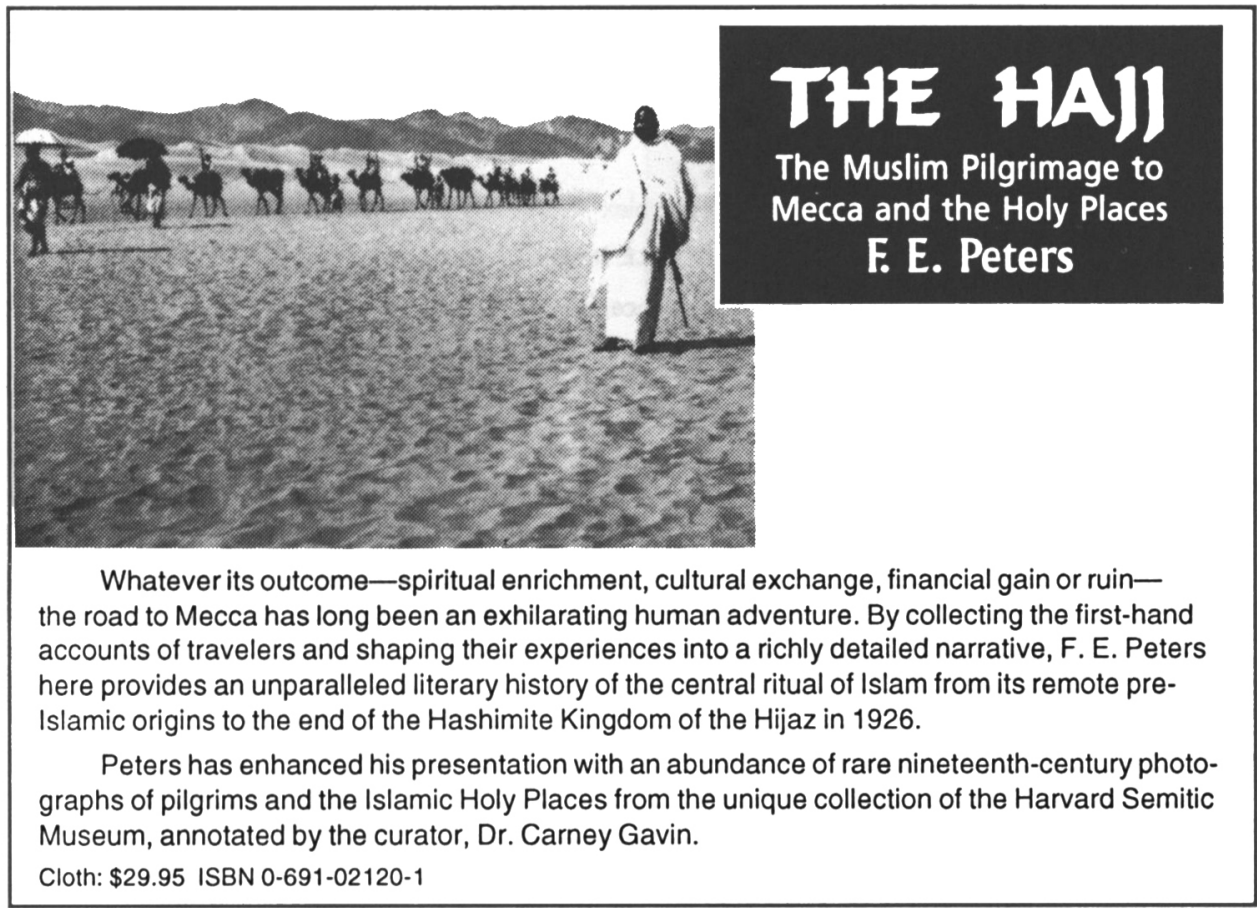

PRINCETON UNIVERSITY PRESS

AVAILABLE AT FINE BOOKSTORES OR DIRECTLY FROM THE PUBLISHER: 609-883-1759 


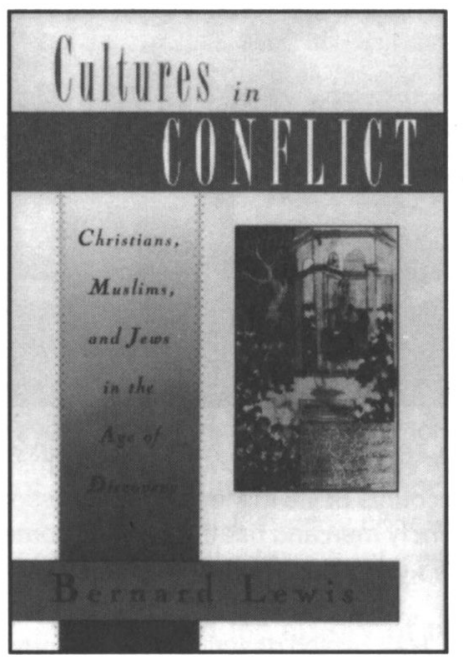

\section{CULTURES IN CONFLICT}

Christians, Muslims, and Jews in the Age of

\section{Discovery}

BERNARD LEWIS

One of the world's foremost historians of Islam examines three pivotal events of 1492-the defeat of the Muslims in Grenada, the expulsion of the Jews from Spain, and the discovery of the New World. With elegance and erudition, Lewis portrays these events as a clash of civilizations-a clash not only of the New World and the Old, but also of

Christendom and Islam, of Europe and the rest of the globe-and he uses these events to illuminate the nature of the European-Islamic conflict. This farreaching discussion of the encounters between Islam, the West, and the globe provides a new understanding of the distant events that gave shape to the modern world.

\section{THE RIVERS OF EDEN}

The Struggle for Water and the Quest for Peace in the Middle East

DANIEL HILLEL

"A fascinating account of the enormously complex water situation in the Middle East." - H.E. Dregne

"Skillfully weaving together the insights of science, history, and ancient lore, Daniel Hillel convincingly demonstrates why peace, development, and environment are inextricably linked. This masterful study... is essential reading for policy makers."

\section{-Steven C. Rockefeller}

"Hillel reminds us of a critical natural resources problem in the Middle East that has serious political, economic, and environmental consequences.... Drawing on his own background experiences, and on an extensive discussion of the work of others, he not only reviews the background leading to the present difficulties, but offers sound advice as to what could and should be done to solve them."

-Nyle C. Brady, United Nations Development Program $\$ 25.00,352 \mathrm{pp}$.

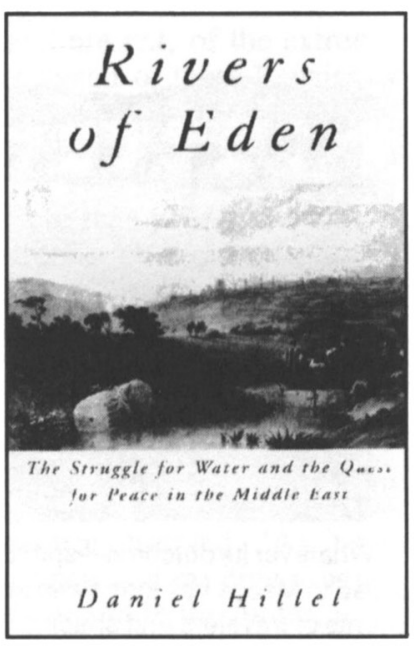


PATRICK D. GAFFNEY The Prophet's Pulpit

Islamic Preaching in Contemporary Egypt

Based on in-depth field research in Egypt, Gaffney focuses on the preacher and the sermon as the single most important medium for propounding the message of Islam.

Comparative Studies on Muslim Societies $\$ 50.00$ cloth, $\$ 20.00$ paper

\section{SEYYED VALI REZA NASR The Vanguard of the Islamic Revolution}

The Jama'at-i Islami of Pakistan In this groundbreaking study, Nasr examines the origins, historical development, and political strategies of one of the oldest and most influential Islamic revival movements, the Jama'at-i Islami of Pakistan. Comparative Studies on Muslim Societies $\$ 50.00$ cloth, $\$ 20.00$ paper

\section{Arabic Short Stories}

Denys Johnson-Davies, Translator Introduction by Roger Allen These stories, translated by one of the finest translators of Arabic fiction, show us the intimate texture of life throughout the diverse countries and cultures of the Arabic world.

$\$ 32.00$ cloth, $\$ 12.00$ paper
SUSAN OSSMAN

Picturing

Casablanca

Portraits of Power in a Modern City

Ossman probes the shape and texture of mass images in Casablanca. She sketches a radically new vision of Casablanca as a place where social practices, traditions, and structures of power are in flux.

$\$ 40.00$ cloth, $\$ 15.00$ paper, illustrated

\section{NAWAL EL SAADAWI}

\section{Memoirs from the Women's Prison}

Translated by Marilyn Booth

Afterword by the Author

"Lively, touching, and highly readable, making us relive with the author the shock of arrest, the dirt and horror of jail, and the nagging uncertainty about when or whether she would be released." - The Middle East $\$ 35.00$ cloth, \$12.00 paper

\section{The Innocence of the Devil}

Translated by Sherif Hitata Introduction by Fedwa Malti-Douglas Set in an insane asylum, The Innocence of the Devil is a complex and chilling novel that recasts the relationships of God and Satan, of good and evil. $\$ 20.00$ cloth 
Manufacturing in the

Ottoman Empire and Turkey,

1500-1950

Donald

Quataert, editor

State University of

New York Press

do CUP Services, PO Box 6525

Ithaca, NY 14851

1-800-222-6611

Please add $\$ 3$ for first copy, $\$ .50$ each additional copy. NY State residents, please add $8 \%$ sales tax. Canadian residents, please add GST. Make checks payable to SUNY Press. VISA, MasterCard, American Express, and Discover accepted.
This book provides the first comprehensive history of manufacturing in the Ottoman Empire and its Turkish successor state.

Suraiya Faroqhi, Mehmet Genç, Donald Quataert, and Çağlar Keyder, experts on different phases of the manufacturing trajectory, provide here exceptional case studies of manufacturing activities in their social and political contexts, integrating first-hand research with surveys of the literature. This work offers rich material for historians, economists, and other social scientists, including those interested in the origins of underdevelopment and development in the contemporary world.

"I found this book particularly interesting because it showed in a vivid, imaginative, and analytical way the internal workings of the Ottoman/ Turkish economy and society, as it concerned manufacturing, and its interaction with and reaction to the West on the level not only of the state but also of the private entrepreneur."

- Elena Frangakis-Syrett, Queens College, City University of New York 
A classic now available in a new paperback edition.

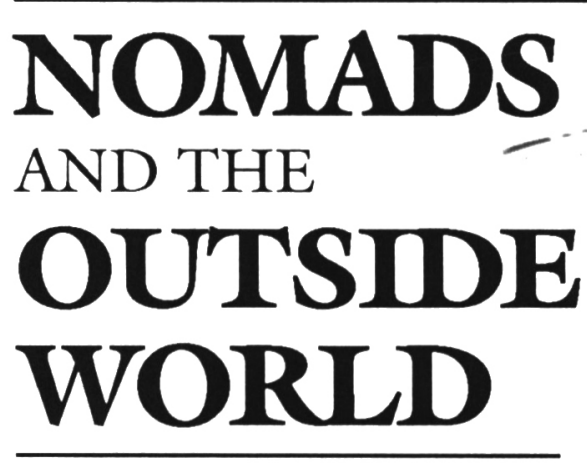

ANATOLY M. KHAZANOV

Translated by Julia Crookenden

Second Edition

With the author's new Introduction and an updated Bibliography

"Magisterial. ... Combining a phenomenal erudition, a candid judgement, and a subtle sense of irony, Khazanov sets out to challenge the orthodox view of nomadic feudalism and, in the process, has produced the first comparative survey of pastoral societies that can claim to be truly comprehensive, covering their history in Eurasia, the Middle East, and Africa from the origins of pastoralism to the dawn of the modern era."

-Tim Ingold, Current Anthropology

"Khazanov's book on pastoral nomadism is a heroic endeavor of a kind no one has seriously attempted before. ... The insights provided by this book are too numerous to list." -Caroline Humphrey, Times Literary Supplement

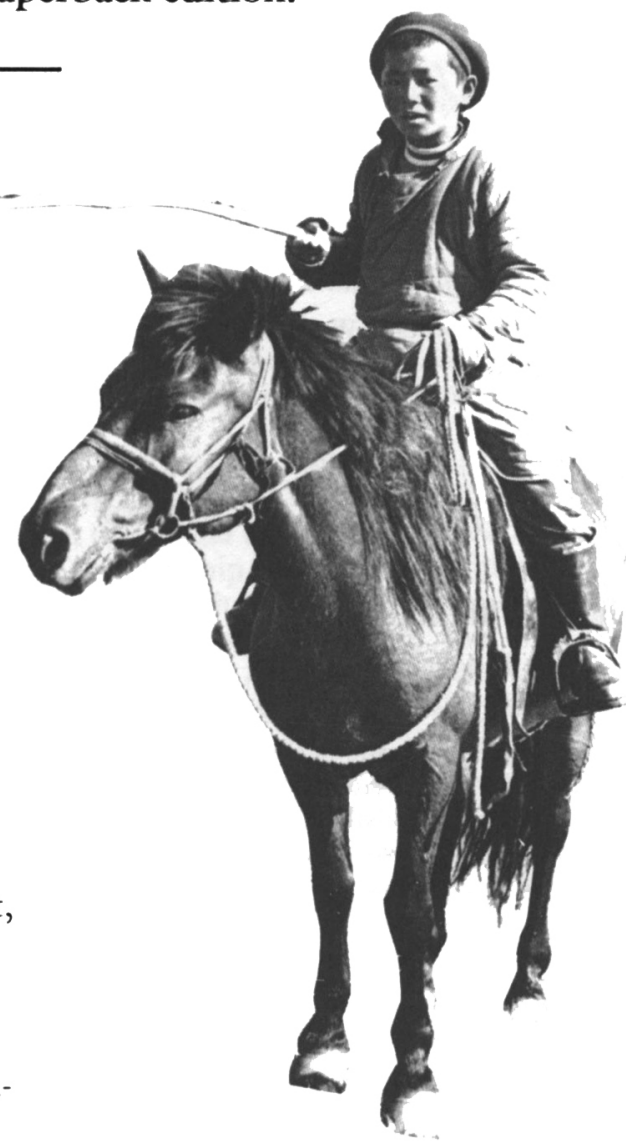

"This is the best study on pastoral nomadism that [I have] ever read. At last we have a major attempt to present the whole phenomenon in historical, ecological, spatial and structural perspective. ... Superb scholarship. It is the kind of work that can only be produced as a result of years of specific research, much deep thinking. . . and a determination to reject cant." -John C. Wilkinson, Geographical Journal paper $\$ 18.50$ 


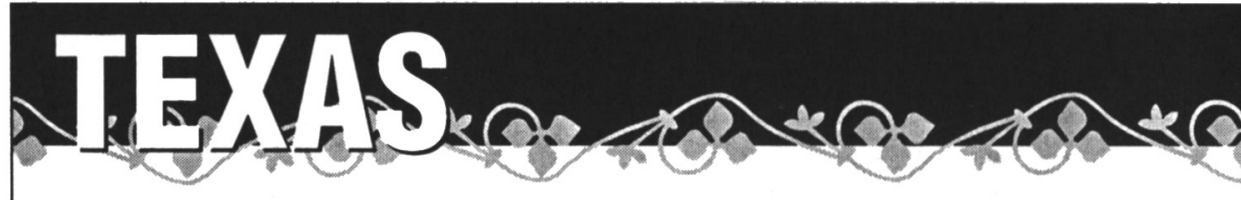

\section{GIVING VOICE TO STONES}

Place and Identity in Palestinian Literature

\section{By Barbara McKean Parmenter}

Exploring the roots of Western and Zionist images of Palestine, Parmenter describes how Palestinian literature struggles with the concept of homeland.

ISBN 0-292-72751-8

$\$ 25.00$ cloth ISBN 0-292-76555-X $\$ 9.95$ paper

\section{THE WAITING LIST}

\section{By Daisy Al-Amir}

Translated by Barbara McKean Parmenter

Set in Iraq, Cyprus, and Lebanon, these contemporary short stories by one of the Arab world's most visible female writers reflect the chaotic worlds of civil war and social transition. (January)

ISBN 0-292-79067-8

$\$ 8.95$ paper

\section{THE UNREADABLE SHORES OF LOVE}

\section{Turkish Modernity and Mystic Romance}

\section{By Victoria Rowe Holbrook}

“Holbrook's brilliant and playful book steals back the sumptuous poetics of $a$ 600 -year tradition camouflaged by vulgar Orientalism and eager occidentalism. ... We envision the mystical union of Beauty and Love both as a glory of Islamic philosophy and a turn in the labyrinths of contem. porary intertextuality." -ORHAN PAMUK

ISBN 0-292-73080-2

ISBN 0-292-73082-9

$\$ 37.50$ cloth $\$ 19.95$ paper

\section{THE WORD OF ISLAM}

\section{Edited by John Alden Williams}

Letting Islam describe itself in its own words, this anthology presents central Islamic writings, some of which have never before appeared in any Western language.

\section{MONEY MAKES US RELATIVES}

Women's Labor in Urban Turkey

By Jenny White

White explores why men and women alike devalue women's work and demonstrates how these ideologies create a pool of cheap labor for the world market.

ISBN 0-292-79077-5

ISBN 0-292-79086-4

$\$ 30.00$ cloth $\$ 12.95$ paper

\section{CHAPTERS ON MARRIAGE AND DIVORCE}

Responses of Ibn Hanbal and Ibn Rahwayh

Translated with introduction and notes by Susan Spectorsky

This work makes available for the first time in English three compilations of family-law rulings issued by two prominent Muslim jurists of the ninth century (third century of Islam), providing basic sources for studying Islamic legal thinking and the status of women in the Muslim world.

ISBN 0-292-77668-3

$\$ 40.00$ cloth

ISBN 0-292-77672-1 $\$ 15.95$ paper

\section{THE ISLAMIC MOVEMENT IN MORTH AFRICA}

\section{By François Burgat and William Dowell}

"The combination of Burgat's expertise and the extensive interviews with leading Islamists make this the best book in English on the subject."

-VIRGINIA QUARTERLY REVIEW

ISBN 0-292-70793-2

$\$ 13.95$ paper

\section{UNIVERSITY OF TEXAS PRESS}

Box 7819 - Austin 78713

To order, call 800-252-3206.

Ask for our free Middle East studies catalog. 
The Middle East Studies Association of North AMERICA, Inc. (MESA) was organized in 1966 by a group of American and Canadian scholars on the Middle East to

- promote high standards of scholarship and instruction in this area;

- facilitate communication among scholars through meetings and publications; and

- foster cooperation among persons and organizations concerned with the scholarly study of the Middle East.

MESA focuses on the study of the Middle East since the rise of Islam, principally from the viewpoint of the humanities and the social sciences. Its membership is international.

Persons of scholarly training and/or achievement in Middle East studies are eligible to become Full Members ( $\$ 60$, Retired $\$ 30$, Joint $\$ 75$ ). Other categories of membership are Associate (\$60), Student (\$30), and Institutional (\$500). Each membership is on a calendar-year basis. Membership includes subscriptions to the International Journal of Middle East Studies, the MESA Bulletin, and the MESA Newsletter. Application forms may be obtained from the MESA Secretariat, 1232 North Cherry Avenue, University of Arizona, Tucson, Arizona $85721,(602) 621-5850$, fax (602) 321-7752.

MESA is a nonprofit corporation with tax-exempt status. Contributions to the Association are deductible under both U.S. Federal and British income tax regulations.

\section{Honorary Fellows: CharLes ISSAWI, MAJid KhadduRI, ANN K.S. LAMBTON, MAXIME RODINSON, ANNEMARIE SCHIMMEL, W. MONTGOMERY WATT Past President: JOHN O. VOLL President: RASHID KHALIDI President-Elect: ANN LESCH}

Directors: 1992-1994: FRED M. DONNER, SUAD JOSEPH 1993-1995: LAURIE BRAND, ZACHARY LOCKMAN 1994-1996: Joel S. BEININ, Elaine C. Hagopian Executive Director \& Treasurer: ANNE H. BETTERIDGE

The following publications are available from the MESA Secretariat (please write for a price list, or fax to 602/321-7752):

- Directory of Graduate and Undergraduate Programs and Courses in Middle East Studies in the United States, Canada, and Abroad. MESA, published biennially.

- Middle East Materials for Teachers, Students, Non-Specialists, ed. by Catherine Jones. Middle East Outreach Council, 1988.

- Text Evaluation Study, of secondary school textbooks, ed. by Elizabeth Barlow. Middle East Outreach Council, 1992.

- Women in the Muslim World: A Bibliography, ed. by Herbert Bodman, Jr. Association for Middle East Women's Studies, 1991.

- Bibliography on Women in Yemen, ed. by Marta Colburn. American Institute for Yemeni Studies, 1992.

- Edited Works and Collections on the Middle East. Annual, Vol 1- (1988-)

- MESA Bulletin Index: Vols. 1-20, 1967-1986.

- Back issues of the MESA Bulletin and Annual Meeting Programs. 


\section{Ethnographic Films By Anthropologist Fadwa El Guindi}

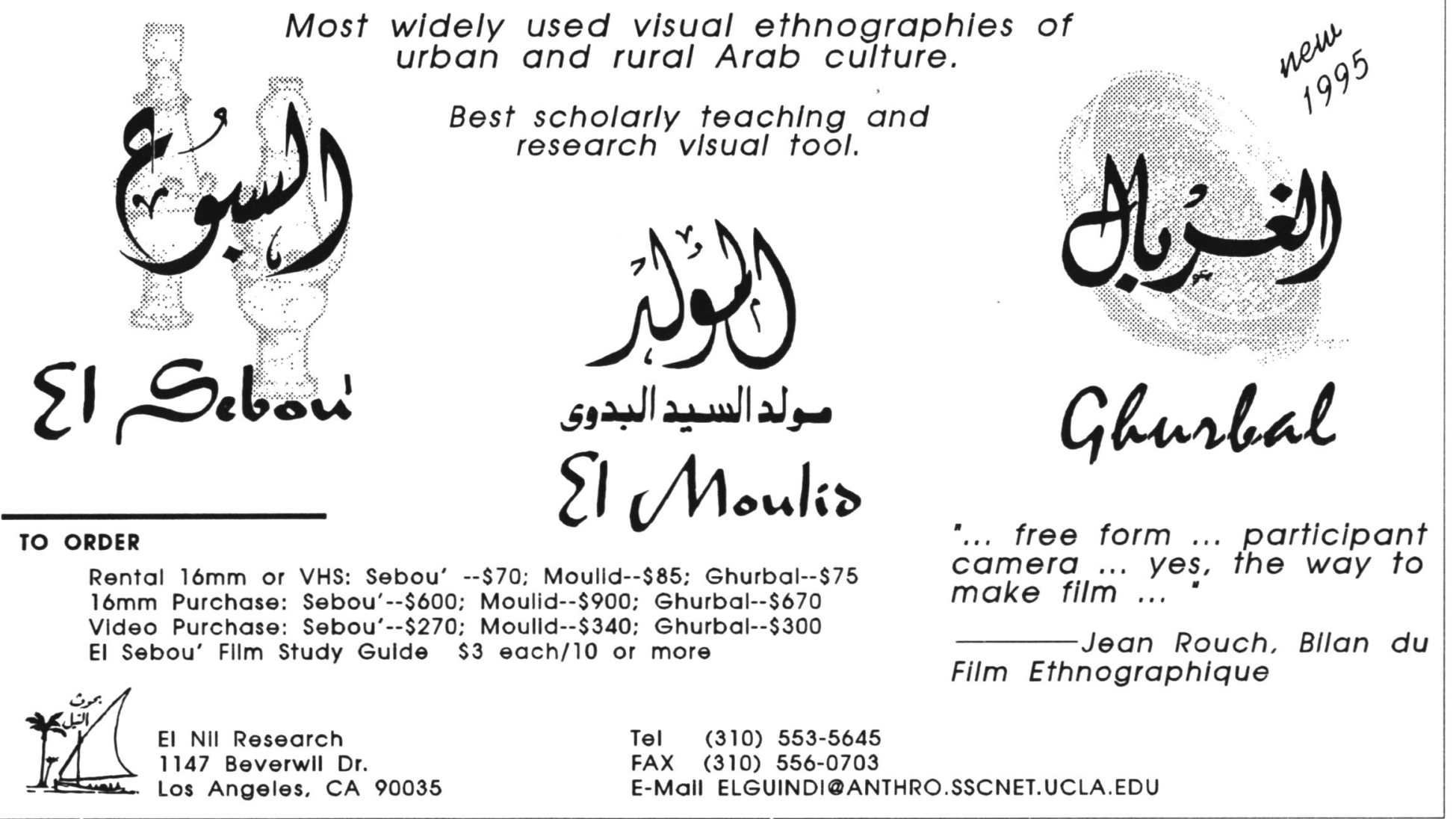

